\title{
Net autotrophy and heterotrophy in the Pontevedra Ria upwelling system (NW Iberian margin)
}

\section{Autotrofia y heterotrofia neta en un sistema costero de afloramiento, la Ría de Pontevedra (noroeste de la plataforma ibérica)}

\author{
Andrew W. Dale \\ Ricardo Prego* \\ Marine Biogeochemistry Research Group \\ Institute of Marine Research (CSIC) \\ 6 Eduardo Cabello, 36208 Vigo, Spain \\ * E-mail: prego@iim.csic.es
}

Recibido en junio de 2003; aceptado en abril de 2004

\begin{abstract}
A non-stationary state mass balance of the type advocated by the International Geosphere-Biosphere Programme/Land-Ocean Interactions in the Coastal Zone (IGBP/LOICZ) has been used to assess net ecosystem metabolism in the Pontevedra Ria (NW Spain), a large embayment subject to transient upwelling of Eastern North Atlantic Central Water (ENACW) under favourable meteorological conditions. Nitrate $\left(\mathrm{NO}_{3}{ }^{-}\right)$and phosphate $\left(\mathrm{PO}_{4}{ }^{3-}\right)$ data spanning 12 months were resolved at the oceanic boundary by treating the ria as a single box of constant volume. The nutrient budget was scaled up to an estimate of net community production (NCP) using the compositional relationship of local phytoplankton. The mean annual $\mathrm{NCP}$ predicted by the $\mathrm{NO}_{3}{ }^{-}$ balance was $24.0 \mathrm{mgC} \mathrm{m}^{-2} \mathrm{~h}^{-1}$, and $35.8 \mathrm{mgC} \mathrm{m}^{-2} \mathrm{~h}^{-1}$ by the $\mathrm{PO}_{4}{ }^{3-}$ budget. Nutrient fluxes into the reservoir were strongly driven by the incoming oceanic flow throughout the year, which supplied $88 \%$ and $98 \%$ of the total $\mathrm{NO}_{3}{ }^{-}$and $\mathrm{PO}_{4}{ }^{3-}$ load, respectively. $\mathrm{A}$ high NCP $\left(\mathrm{NO}_{3}^{-}\right)$of $57.2 \mathrm{mgC} \mathrm{m} \mathrm{m}^{-2} \mathrm{~h}^{-1}$ was calculated for the height of the growth season contemporaneous with ENACW intrusion, whereas a slightly higher value of $61.4 \mathrm{mgC} \mathrm{m}^{-2} \mathrm{~h}^{-1}$ corresponded to $\mathrm{PO}_{4}{ }^{3-}$. Nutrient limitation was variable throughout the sampling, switching from $\mathrm{PO}_{4}{ }^{3-}$ to $\mathrm{NO}_{3}{ }^{-}$from winter to spring concurrent with a drop in riverine $\mathrm{PO}_{4}{ }^{3-}$ input. Scaling the inorganic nutrients to carbon units, the Pontevedra Ria may be considered as net autotrophic, although the $\mathrm{NO}_{3}{ }^{-}$budget suggests alternation between autotrophy and heterotrophy over an annual cycle.
\end{abstract}

Key words: upwelling, nutrient budget, Pontevedra Ria, NW Spain.

\section{Resumen}

Se aplicó un balance no estacionario, siguiendo el modelo aconsejado por el programa IGBP-LOICZ, para calcular el metabolismo neto del ecosistema en la Ría de Pontevedra, un sistema costero sujeto a eventos de afloramiento de ENACW (Agua Central del Noreste Atlántico) bajo condiciones meteorológicas favorables. Para realizar dicho balance se utilizaron los datos de nitrato y fosfato obtenidos durante un lapso de doce meses en la frontera oceánica de la ría, considerada ésta como un único compartimento de volumen constante. Se estimó la producción neta (NCP, net community production) en base al balance de nutrientes y la composición elemental del fitoplancton local, obteniéndose un valor medio anual de $24.0 \mathrm{mgC} \mathrm{m}^{-2} \mathrm{~h}^{-1}$ en base al nitrato y de $35.8 \mathrm{mgC} \mathrm{m}^{-2} \mathrm{~h}^{-1}$ a partir del fosfato. El aporte de nutrientes hacia el compartimento fue muy dependiente del flujo entrante desde el océano a lo largo del año ya que éste contribuye con $88 \%$ y $98 \%$ del nitrato y fosfato total recibido, respectivamente. El máximo de NCP, $57.2 \mathrm{mgC} \mathrm{m}^{-2} \mathrm{~h}^{-1}$ en base al nitrato y $61.4 \mathrm{mgC} \mathrm{m}^{-2} \mathrm{~h}^{-1}$ partiendo del fosfato, se obtuvo durante la época de floraciones coetáneas a la intrusion de ENACW en la ría. La limitación de nutrientes fue variable durante todo el periodo de muestreo, cambiando del fosfato al nitrato desde el invierno hasta la primavera de acuerdo con la baja entrada de fosfato fluvial. Al convertir los nutrientes inorgánicos en unidades de carbono, la ría de Pontevedra puede ser considerada por su balance neto anual como autótrofa, aunque el balance de nitrato sugiere una alternancia entre autotrofía y heterotrofía durante el ciclo anual.

Palabras clave: nutriente, balance, afloramiento, ría, Pontevedra, NO de España.

\section{Introduction}

Under normal estuarine spatial and temporal constraints, reactive materials such as nutrients behave non-conservatively owing to modifications by biological recycling and chemical

\section{Introducción}

En condicciones estuáricas normales, desde un punto de vista espacial o temporal, las sustancias reactivas como las sales nutrientes presentan un comportamiento no conservativo 
transformations acting independently over simple physical advection and mixing. Nutrient mass balances, or box models (Nixon et al., 1995; Kemp et al., 1997), constitute a useful tool to assess the degree of non-conservatism within spatially and temporally defined boundaries. The nutrient budget can give valuable information as to whether the system is a net exporter or importer of nutrients. Smith and Hollibaugh (1997) used the term "trophic status" to describe the balance (net respiration or net synthesis) of organic carbon in an ecosystem, where heterotrophic refers to net organic carbon respiration and autotrophic refers to net organic carbon synthesis. The trophic status can be broadly inferred from inorganic nutrient budgets after the net nutrient flux has been scaled to net organic carbon flux stoichiometric linking according to the chemical composition of photosynthezised organic matter. Clearly, differences may arise depending on which nutrient (either $\mathrm{N}$ or $\mathrm{P}$ ) is taken as the baseline for stoichiometric linking.

Recent projects in the Galician Rias, NW Spain, have focused on the development of nutrient budgets (Prego, 1993a, 1994; Álvarez-Salgado et al., 1996; Rosón et al., 1999). This work focuses on the Pontevedra Ria, one of four large embayments on the western Galician coast known collectively as the Rias Bajas. The Rias Bajas are host to one of the world's largest fisheries of the edible mussel Mytilus edulis, whose production may reach 100,000 $\mathrm{t} \mathrm{yr}^{-1}$ in the Arosa Ria (Tenore et al., 1982). The most pronounced hydrographical feature of these rias is upwelling (Fraga, 1981) of East North Atlantic Central Water (ENACW, $\mathrm{S}=35.67-35.83, \theta=11.8-13.5^{\circ} \mathrm{C}$; Fiuza et al., 1998). Upwelling normally occurs from April to October engendered by spatial shifts of the North Atlantic Azores anticyclone and offshore Ekman transport (Wooster et al., 1976; McClain et al., 1986), although under suitable conditions, offshore water masses may intrude into the Pontevedra Ria outside of the upwelling season (Prego et al., 2001). ENACW is rich in remineralized inorganic nutrients and supports the extensive raft-culture of mussels and high primary productivity (Álvarez-Salgado et al., 1996). At other times of the year terrestrial runoff is the dominant nutrient supply. Thus, the rias and adjacent shelf waters can be envisaged as a collage of intricate hydrographic regimes acting to enhance remineralization and primary production both inside the rias and on the continental shelf (Prego, 1993a).

The objective of this paper is to explore the annual net ecosystem metabolism in the Pontevedra Ria by means of a non-stationary state time-series mass balance. Inorganic nutrient fluxes are resolved across the budget front where oceanic- and fluvial-dominated hydrographic regimes meet.

\section{Materials and methods}

The field campaign took place between October 1997 and October 1998, over 23 transects on board the R/V Mytilus. Water samples for chemical analysis were collected from six stations along the ria axis (fig. 1) using General Oceanic Niskin bottles at standard depths and separated into $50-\mathrm{mL}$ debido a un reciclado biológico y a reacciones químicas que ocurren independientemente de los simples procesos físicos de advección y mezcla. A ese respecto, los balances de nutrientes mediante modelos de cajas (Nixon et al., 1995; Kemp et al., 1997) constituyen una herramienta útil para calcular el grado de no conservatividad dentro de unos límites, tanto espaciales como temporales, definidos previamente. Un balance de nutrientes es capaz de proporcionar información valiosa sobre si un sistema es exportador o importador neto de nutrientes. Smith y Hollibaugh (1997) han empleado el término de "estado trófico” para describir el balance (respiración neta o síntesis neta) de carbono orgánico en un ecosistema donde heterotrofía significa un consumo neto de carbono orgánico en la respiración y autotrofía como una síntesis neta de carbono orgánico. En general, el estado trófico puede inferirse a partir de un balance de sales nutrientes toda vez que el flujo neto de nutrientes se puede expresar como un flujo neto de carbono orgánico mediante su “conversión estequiométrica”, según la composición química de la materia orgánica fotosintétizada. Obviamente, pueden surgir algunas diferencias dependiendo del nutriente (nitrato o fosfato) considerado como referencia para la dicha conversión.

Algunos proyectos recientes en las rías gallegas (NO de España) han abordado el desarrollo de balances de nutrientes (Prego, 1993a, 1994; Álvarez-Salgado et al., 1996; Rosón et al., 1999) y el presente trabajo lo hace en la Ría de Pontevedra, uno de los cuatro grandes sistemas costeros de la plataforma occidental gallega, conocidos conjuntamente como las Rías Bajas. Ellas son el hogar de una de las mayores áreas de cultivo del mejillón comestible Mytilus edulis, cuya producción comercial puede alcanzar las 100,000 toneladas al año en la Ría de Arosa (Tenore et al., 1982). El fenómeno hidrográfico más destacado en esas rías es el afloramiento marino (Fraga, 1981) de Agua Central del Atlántico Noreste (ENACW, S = 35.67-35.83, $\theta=11.8-13.5^{\circ} \mathrm{C}$; Fiuza et al., 1998). Los eventos de afloramiento se suceden normalmente desde abril hasta octubre debido a la posición del anticiclón de las Azores y el transporte de Ekman (Wooster et al., 1976; McClain et al., 1986), aunque bajo condiciones apropiadas el agua del talud continental puede penetrar en la Ría de Pontevedra en fechas diferentes a las consideradas como "estación del afloramiento" (Prego et al., 2001). ENACW es una masa de agua rica en nutrientes inorgánicos remineralizados, lo que permite mantener una elevada producción primaria (Álvarez-Salgado et al., 1996) con el consiguiente cultivo extensivo de mejillones en bateas. De esta manera, el agua de las rías y su plataforma continental adyacente pueden entenderse como un mosaico de complejos regímenes hidrográficos que actuan incrementando la remineralización y la producción primaria, tanto dentro de las rías como sobre la plataforma continental (Prego, 1993a).

El objetivo de este artículo es investigar el metabolismo anual neto del ecosistema en la Ría de Pontevedra mediante una serie temporal de balances no estacionarios. En ellos, los 
HDPE bottles. CTD data were collected from eleven stations in the ria with a Sea-bird SBE 19. Water samples were generally analyzed for phosphate $\left(\mathrm{PO}_{4}{ }^{3-}\right)$ and nitrate $\left(\mathrm{NO}_{3}{ }^{-}\right)$within $24 \mathrm{~h}$, following established autoanalytical colorimetric techniques (Hansen and Grasshoff, 1983). Ten replicate analyses of different aliquots of equal concentrations yielded the following standard deviations: $\mathrm{NO}_{3} \pm 0.01$ (within the $0-10 \mu \mathrm{M}$ range) and $\mathrm{PO}_{4}{ }^{3-} 0.03(0-2 \mu \mathrm{M})$.

\section{Frontal budget development}

The budget framework closely follows the Land Ocean Interactions in the Coastal Zone (LOICZ) protocol for budget modelling developed by Gordon et al. (1996). The ria is treated as a single partially mixed box (volume $1.47 \mathrm{~km}^{3}$, area $68.6 \mathrm{~km}^{2}$ ), with boundaries at the limit of tidal influence at the ria head, and at the cross section between Udra Cape and Cabicastro Point at the seaward end (fig. 1).

The Lérez River provides the main freshwater input to the ria (mean annual discharge $25.9 \mathrm{~m}^{3} \mathrm{~s}^{-1}$; Ibarra and Prego, 1997), and there is a small discharge from the sewage works, with a mean daily rate of $0.41 \mathrm{~m}^{3} \mathrm{~s}^{-1}$. River flow was recorded daily at a gauging station at the limit of tidal influence. Seasonality in the region can be defined by the river flow, comprising the wet season (November-February), spring (March-May) and the dry season (June-September), with October being a transitional month.

The water balance of the ria of constant volume, $V$, comprises the river runoff, $Q_{r}$, sewage inputs, $Q_{s}$, and direct precipitation, $Q_{p}$, and water losses via evaporation, $Q_{e}$ (fig. 2). If the sum of these parts (expressed in $\mathrm{m}^{3} \mathrm{~s}^{-1}$ ) is the net residual flow, $Q_{z}$, then (assuming negligible groundwater inputs):

$$
\frac{d V}{d T}=Q_{r}+Q_{s}+Q_{p}+Q_{e}+Q_{z}=0
$$

If $Q_{z}<0$ then net residual flow out of the ria is implied. Assuming zero salinity for $Q_{r}, Q_{p}, Q_{s}$ and $Q_{e}$, the horizontal exchange fluxes for each cruise can be evaluated individually with the following equations (Gordon et al., 1996):

$$
\begin{gathered}
Q_{i}=\frac{1}{\left(S_{i}-S_{o}\right)}\left[Q_{z} S_{o}+V \frac{d S_{o}}{d T}\right] \\
Q_{o}=\frac{1}{\left(S_{i}-S_{o}\right)}\left[Q_{z} S_{o}+V \frac{d S_{o}}{d T}\right]+Q_{Z}
\end{gathered}
$$

where $Q_{i}$ and $Q_{o}$ are the water exchanges (by advection and mixing) in and out of the system, respectively, with average salinities of $S_{i}$ and $S_{o}$ (measured at station $\mathrm{S}$ on the seaward boundary). In this work, $S_{o}$ is defined as the average salinity of the ria, $d S_{o} / d T$ is the change in outgoing salinity between each flujos de sales nutrientes se cuantificaron a través de una frontera en la ría, la cual se considera como un compartimento hidrográficamente dominado por los regímenes fluvial y oceánico.

\section{Material y métodos}

Las campañas marinas tuvieron lugar entre octubre de 1997 y octubre de 1998 con un total de 23 transectos realizados en el B/I Mytilus. Durante ellos se recolectaron muestras de agua para análisis químicos en seis estaciones distribuidas a lo largo del eje de la ría (fig. 1) empleando botellas oceanográficas Niskin General Oceanic que se cerraron a profundidades estándar $(0,5,10,20,30,40 \mathrm{~m})$, y de las que se extrajeron 50 $\mathrm{mL}$ de agua que fueron almacenados en frascos de plástico (HDPE). Además, en once estaciones emplazadas dentro de la ría se midieron perfiles verticales de salinidad y temperatura mediante una sonda CTD marca Sea-bird SBE 19. Normalmente, en las muestras de agua se analizó nitrato y fosfato el mismo día de su toma, siguiendo las técnicas autoanalíticas colorimétricas clásicas establecidas (Hansen y Grasshoff, 1983). Para ello, se determinó la desviación estandar del método a partir de diez réplicas de igual concentración, siendo de $\left[\mathrm{NO}_{3}{ }^{-}\right] \pm 0.01$ para el rango $0-10 \mu \mathrm{M}$ y de $\left[\mathrm{PO}_{4}{ }^{3-}\right] \pm 0.03$ para el intervalo $0-2 \mu \mathrm{M}$.

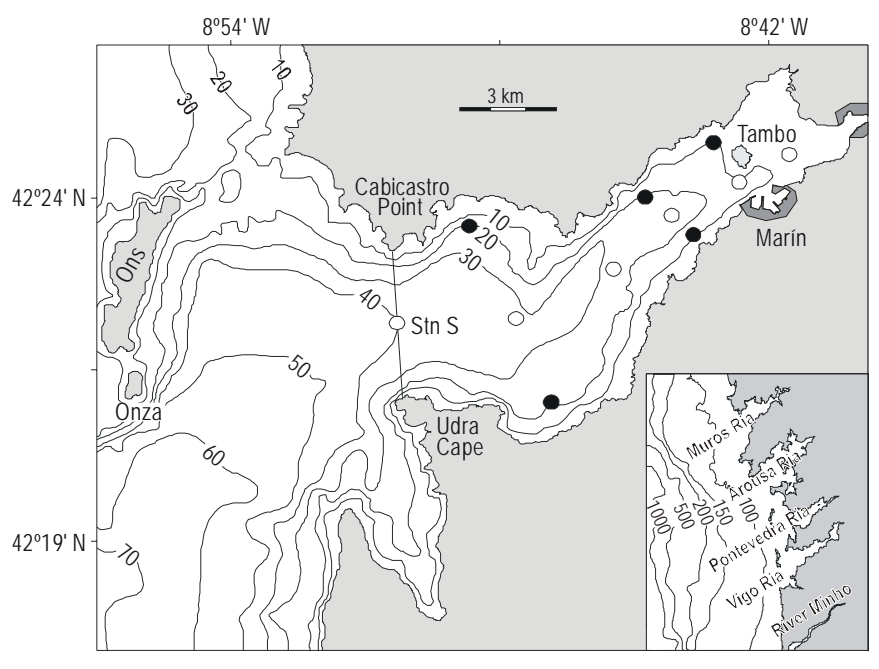

Figure 1. Map of the Pontevedra Ria on a local and regional scale. The City of Pontevedra and the Lérez River mouth are located at the ria head in the top right-hand corner of the map. Station $\mathrm{S}$ is indicated on the seaward budget front (solid line). CTD data were collected at all sampling stations $(\bullet$ and $O$ ), while nutrient data were collected at stations marked with empty circles only (O).

Figura 1. Mapa de la Ría de Pontevedra a escala local y regional. En la cabecera de la ría (esquina superior derecha del mapa), se halla la ciudad de Pontevedra y la desembocadura del Río Lérez. La estación S se encuentra en la fontera marina del compartimento (línea contínua). Los datos registrados con el CTD se midieron en todas las estaciones ( $\bullet$ y 0 ) mientras que los datos de sales nutrientes solamente se analizaron en las estaciones marcadas con círculos vacíos (O). 


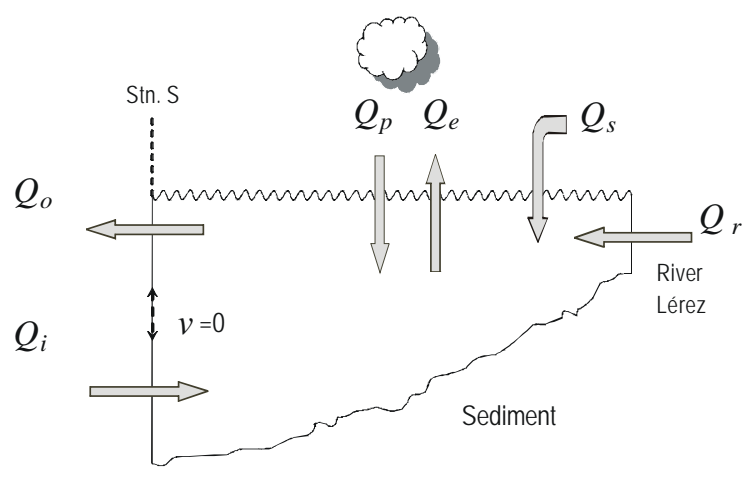

Figure 2. Reservoir representation of the water budget in the Pontevedra Ria. The boundaries of the box correspond to station $S$ on the seaward side and the Lérez River on the landward side. $Q_{o}, Q_{i}, Q_{r}, Q_{s}, Q_{p}$ and $Q_{e}$ refer, respectively, to water exchanges due to outgoing, incoming, river and sewage flows, precipitation and evaporation. The level of separation between the incoming and outgoing layers at station $S$ (level of zero motion) is indicated by $v=0$.

Figura 2. Compartimento definido en la Ría de Pontevedra para el balance de agua. Sus fronteras corresponden a la estación $\mathrm{S}$, marina, y al Río Lérez, terrestre. $Q_{o}, Q_{i}, Q_{r}, Q_{s}, Q_{p}$ y $Q_{e}$ se refieren, respectivamente, a los flujos de agua saliente, entrante, fluvial, aguas residuales, de lluvia y evaporación. El nivel de separación entre las capas de agua entrante y saliente en la estación $\mathrm{S}$ se indica por $v=0$ (nivel de velocidad nula).

cruise, and $S_{i}$ on the budget front was calculated using the water density to derive the level of zero velocity $(v=0$, fig. 2$)$ separating the two layers.

\section{Inorganic budget and stoichiometric linkage}

The net flux, $\Sigma F$, of non-conservative material across the budget boundary is quantified as the sum of the products of the individual water fluxes (fig. 2) and the concentration, $c$, of dissolved material therein:

$$
\Sigma F=F_{o}-F_{i}-F_{r}-F_{S}
$$

where the subscripts correspond to those in eq. (1). Similarly, the sum of the net non-conservative biogeochemical processes, which cause deviations in simple constituent mixing, can be represented by $B_{p}$ and a non-steady state term $d N_{u} / d T$ :

$$
B_{p}=V \frac{d N_{u}}{d T}+\Sigma F
$$

If no biogeochemical removal or addition of nutrient salts takes place, $\Sigma F$ will be purely dependent on physical mixing and transport processes, and therefore be zero. The seasonal and annual results for $B_{p}$ are shown in table 1 .

Net community production (NCP) refers to organic nutrient production and is the difference between gross primary production and respiration. NCP (in $\mathrm{mgC}_{\text {org }} \mathrm{m}^{-2} \mathrm{~h}^{-1}$ ) can be estimated as $B_{p}$, using the C:N:P ratio of $129: 17: 1$ for local

\section{Desarrollo del balance a través de una frontera}

El planteamiento del balance sigue en detalle el protocolo establecido por LOICZ (Land Ocean Interactions in the Coastal Zone) para el modelado de balances de materia desarrollado por Gordon et al. (1996). La ría es considerada como un compartimento único parcialmente mezclado $\left(1.47 \mathrm{~km}^{3}\right.$ de capacidad y área de $68.6 \mathrm{~km}^{2}$ ), cuyo límite terrestre se fija en su cabecera, donde termina la influencia mareal, y el marino en una sección transversal definida entre Cabo Udra y Punta Cabicastro (fig. 1). El Río Lérez es el principal proveedor de agua dulce a la ría (25.9 $\mathrm{m}^{3} \mathrm{~s}^{-1}$ de caudal medio anual; Ibarra y Prego, 1997) aunque existe además una pequeña descarga de aguas residuales del área urbana pontevedresa que supone un caudal medio diario de $0.41 \mathrm{~m}^{3} \mathrm{~s}^{-1}$. Durante el año de las campañas marinas, el caudal fluvial se midió en una estación de aforo situada en el límite de la influencia mareal. Los cambios estacionales se pueden definir correctamente a través del caudal fluvial y corresponden a una época húmeda (noviembre a febrero), otra primaveral (marzo a mayo) y una tercera seca (junio a septiembre) con un mes de transición (octubre).

El balance de agua para una ría de volumen constante, $V$, comprende el aporte fluvial, $Q_{r}$, el de agua residual, $Q_{s}$, la precipitación directa, $Q_{p}$, y las pérdidas de agua vía evaporación, $Q_{e}$ (fig. 2). Si la suma de estos caudales (v.g., expresados en $\mathrm{m}^{3} \mathrm{~s}^{-1}$ ) es el flujo neto residual de agua, $Q_{z}$, entonces (suponiendo que son despreciables los debidos a aguas subterráneas hacia la ría) se cumple que:

$$
\frac{d V}{d T}=Q_{r}+Q_{s}+Q_{p}+Q_{e}+Q_{z}=0
$$

donde $Q_{z}$ es negativo cuando el flujo residual neto es hacia afuera de la ría.

Suponiendo que la salinidad del agua para $Q_{r}, Q_{p}, Q_{s}$ y $Q_{e}$ sea prácticamente nula, los flujos de intercambio horizontal se pueden evaluar individualmente en cada campaña de acuerdo a (Gordon et al., 1996) las ecuaciones siguientes:

$$
\begin{gathered}
Q_{i}=\frac{1}{\left(S_{i}-S_{o}\right)}\left[Q_{Z} S_{o}+V \frac{d S_{o}}{d T}\right] \\
Q_{O}=\frac{1}{\left(S_{i}-S_{o}\right)}\left[Q_{Z} S_{o}+V \frac{d S_{o}}{d T}\right]+Q_{Z}
\end{gathered}
$$

donde $Q_{i}$ y $Q_{o}$ son los intercambios de agua (por advección y mezcla) entrante y saliente en el sistema ría, y que tienen salinidades medias respectivas $S_{i}$ y $S_{o}$ (medidas en la estación $\mathrm{S}$, frontera marina); $S_{o}$ se define aquí como la salinidad media del agua contenida en la ría; $d S_{o} / d T$ es el cambio en la salinidad saliente entre cada campaña; $S_{i}$ en la frontera del compartimento se calculó a partir del nivel de velocidad cero $(v=0$, fig. 2) que separa las dos capas definidas con base en la densidad del agua. 
Table 1. Seasonal and annual nutrient balance in the Pontevedra Ria $\left(B_{p}\right.$, Eq. 5) over the period November 1997 to September 1998. A negative sign denotes a net loss of inorganic nutrients from the ria and a positive sign denotes a net input. Units are in $\mathrm{mol} \mathrm{s}^{-1}$ and in equivalent carbon units.

Tabla 1. Balance estacional y anual de nutrientes en la Ría de Pontevedra $\left(B_{p}\right.$, Eq. 5) para el período de noviembre de 1997 hasta septiembre de 1998. Un signo negativo indica una pérdida neta de sales nutrientes en la ría y otro positivo denota una ganancia neta. Las unidades están en $\mathrm{mol} \mathrm{s}^{-}$ ${ }^{1}$ de nitrato y fosfato, así como sus equivalentes en carbono.

\begin{tabular}{lrcrcc}
\hline \multirow{2}{*}{ Season } & \multicolumn{2}{c}{$\mathrm{NO}_{3}^{-}$} & & \multicolumn{2}{c}{$\mathrm{PO}_{4}{ }^{3-}$} \\
\cline { 2 - 3 } \cline { 5 - 6 } & $\mathrm{mol} \mathrm{s}^{-1}$ & $\mathrm{mgC} \mathrm{m}^{-2} \mathrm{~h}^{-1}$ & & $\mathrm{~mol} \mathrm{~s}^{-1}$ & $\mathrm{mgC} \mathrm{m}^{-2} \mathrm{~h}^{-1}$ \\
\hline Wet & 1.74 & 8.3 & & -0.25 & -20.2 \\
Spring & -4.58 & -21.9 & & -0.28 & -22.7 \\
Dry & -11.98 & -57.2 & & -0.76 & -61.4 \\
Mean & -5.03 & -24.0 & & -0.44 & -35.8 \\
\hline
\end{tabular}

phytoplankton (Ríos and Fraga, 1987), assuming that loss of inorganic material is equal to the gain in organic material via photosynthesis. The time-series NCP for the Pontevedra Ria is shown in figure 3.

\section{Results and discussion}

\section{Seasonal nutrient dynamics and NCP}

Wet season

The highest nutrient fluxes from the Lérez River occurred in the wet season, with average flow concentrations of $30 \mu \mathrm{M} \mathrm{NO}_{3}{ }^{-}$and $0.12 \mu \mathrm{M} \mathrm{PO}_{4}{ }^{3-}$ (data not shown). The nutrient fluxes were modified from conservative mixing, and table 1 shows that $\mathrm{PO}_{4}{ }^{3-}$ was retained in the ria at a rate of $-0.25 \mathrm{~mol}$ $\mathrm{PO}_{4}{ }^{3-} \mathrm{s}^{-1}$, whereas for $\mathrm{NO}_{3}{ }^{-}$there appears to be a net source of $1.74 \mathrm{~mol} \mathrm{NO}_{3}{ }^{-} \mathrm{s}^{-1}$, possibly from the resuspension and aerobic bacterial decomposition of the bed nutrient stock. These observations for $\mathrm{NO}_{3}{ }^{-}$further characterize the rapid organic nitrogen recycling relative to consumption during low phytoplankton activity and the dominance of physical over biogeochemical processes. Similar findings have been reported for the Vigo Ria (Prego, 1994). The average NCP in Pontevedra predicted by $\mathrm{PO}_{4}{ }^{3-}$ from November to February was comparatively low at $-20.2 \mathrm{mgC} \mathrm{m}^{-2} \mathrm{~h}^{-1}$ (table 1); however, some $\mathrm{PO}_{4}{ }^{3-}$ may be retained in inorganic sorption reactions, thus giving apparent $\mathrm{PO}_{4}^{3-}$ uptake (Prego, 1993b). Conversely, $\mathrm{NO}_{3}{ }^{-}$ predicts negative NCP, or net remineralization in the water column, at a rate of $8.3 \mathrm{mgC} \mathrm{m}{ }^{-2} \mathrm{~h}^{-1}$. Figure 3 shows the evolution of $\mathrm{NO}_{3}^{-}-\mathrm{NCP}$ and tendency toward heterotrophy. Net heterotrophy in Chesapeake Bay, USA (Smith and Kemp, 1995), was attributed to influxes and remineralization of riverborne allochthonous organic matter (GPP: respiration <1, where GPP is the gross primary production).

\section{El balance inorgánico y su relación con la estequimetría}

El flujo neto, $\Sigma F$, de sustancias no consevativas a través de la frontera del compartimento ría se cuantifica como la suma del producto de cada flujo de agua (fig. 2) por la concentración, $c$, del material disuelto que contiene:

$$
\Sigma F=F_{o}-F_{i}-F_{r}-F_{s}
$$

donde los subíndices se corresponden con los de la ecuación (1). De manera similar, la suma de los procesos biogeoquímicos no conservativos, los cuales hacen que sea diferente de una simple mezcla de sustancias, puede representarse por $B_{p}$ y un término no estacionario $d N_{u} / d T$ :

$$
B_{p}=V \frac{d N_{u}}{d T}+\Sigma F
$$

Si no hay aporte o eliminación de sales nutrientes por procesos biogeoquímicos, $\Sigma F$ sólo dependerá de procesos físicos de transporte o mezcla, y por lo tanto será cero. Los resultados estacionales y anuales para $B_{p}$ se indican en la tabla 1 .

La producción neta (NCP, net community production) corresponde a la síntesis de materia orgánica y es la diferencia entre la producción primaria bruta y la respiración. NCP (en $\mathrm{mgC}_{\text {org }} \mathrm{m}^{-2} \mathrm{~h}^{-1}$ ) puede estimarse como $B_{p}$, si se considera la relación C:N:P de 129:17:1 para el fitoplancton local (Ríos y Fraga, 1987), suponiendo que la pérdida de materia inorgánica es igual a la ganancia de materia orgánica mediante la fotosíntesis. Las series temporales de NCP para la Ría de Pontevedra se muestran en la figura 3.

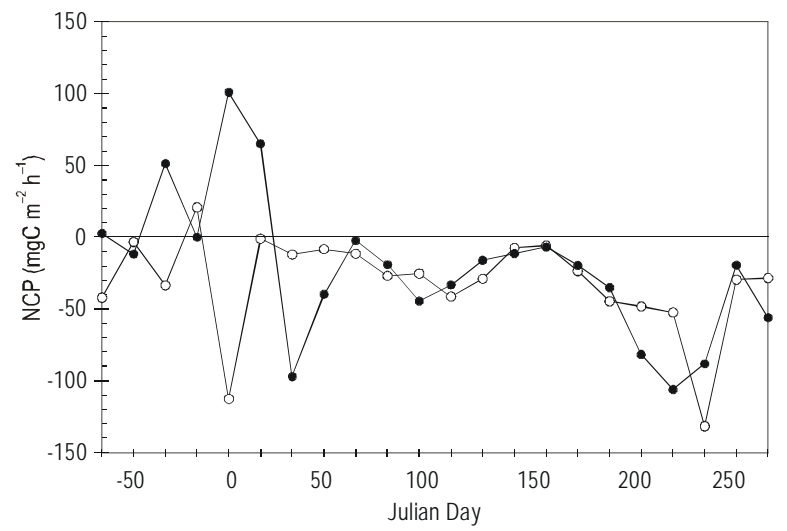

Figure 3. Time series of net community production (NCP, $\mathrm{mgC} \mathrm{m}^{-2} \mathrm{~h}^{-1}$ ) in the Pontevedra Ria from October 1997 to October 1998 scaled from $\mathrm{NO}_{3}{ }^{-}$ $(\bullet)$ and $\mathrm{PO}_{4}{ }^{3-}(\mathrm{O})$ nutrient balances $\left(B_{p}\right.$, Eq. 5). A positive value implies net heterotrophy and a negative value, net autotrophy.

Figura 3. Series de tiempo para la producción neta (NCP, $\mathrm{mgC} \mathrm{m}^{-2} \mathrm{~h}^{-1}$ ) en la Ría de Pontevedra durante el período de octubre de 1997 a octubre de 1998 indicadas como balance $\left(B_{p}\right.$, Ec. 5) de nitrato $(\bullet)$ y fosfato (O). Un valor positivo (negativo) supone una heterotrofía (autotrofía) neta. 


\section{Spring}

Spring incoming nutrient concentrations from the ocean were lower than in the wet season (data not shown), although higher fluxes occurred with sporadic upwelling events due to organic matter oxidation outside the reservoir (Prego, 1994), as occurs in other upwelling systems (e.g., Friedrich and Codispoti, 1981). The nutrient input was assimilated by the phytoplankton thriving under hydrodynamic control and the ria became a nutrient sink, retaining $-0.28 \mathrm{~mol} \mathrm{PO}_{4}{ }^{3-} \mathrm{s}^{-1}$ and $-4.58 \mathrm{~mol} \mathrm{NO}_{3}{ }^{-} \mathrm{s}^{-1}$ (table 1). Mean values of NCP in spring were $-21.9 \mathrm{mgC} \mathrm{m}^{-2} \mathrm{~h}^{-1}$ based on $\mathrm{NO}_{3}{ }^{-}$and $-22.7 \mathrm{mgC} \mathrm{m}{ }^{-2} \mathrm{~h}^{-1}$ based on $\mathrm{PO}_{4}^{3-}$. Spring bloom values of $-42 \mathrm{mgC} \mathrm{m}^{-2} \mathrm{~h}^{-1}$ have been reported for the Arosa Ria (Tenore et al., 1982). This spring nutrient sink may be regarded as the synthesis of organic nutrients from the use of offshore or allochthonous $\mathrm{NO}_{3}{ }^{-}$to the reservoir, analogous to new production (Epply and Peterson, 1979).

\section{Dry season}

In September 1998 river runoff fell to $1.4 \mathrm{~m}^{3} \mathrm{~s}^{-1}$ and fluvial $\mathrm{NO}_{3}{ }^{-}$and $\mathrm{PO}_{4}{ }^{3-}$ inputs formed less than $3 \%$ and $1 \%$ of total ria input, respectively (data not shown). Conversely, offshore $\mathrm{NO}_{3}{ }^{-}$and $\mathrm{PO}_{4}{ }^{3-}$ inputs supplied $97 \%$ and $>99 \%$, respectively, of the total nutrient input to the ria, at a rate of $15.8 \mathrm{~mol} \mathrm{NO}_{3}{ }^{-} \mathrm{s}^{-1}$ and $1.02 \mathrm{~mol} \mathrm{PO}_{4}{ }^{3-} \mathrm{s}^{-1}$. Increased nutrient removal from spring to the dry season led to net removal rates of $-11.98 \mathrm{~mol} \mathrm{NO}_{3}{ }^{-} \mathrm{s}^{-1}$ and $-0.76 \mathrm{~mol} \mathrm{PO}_{4}^{3-} \mathrm{s}^{-1}$ (table 1), and contributed the major part to the annual nutrient sink of $-5.03 \mathrm{~mol} \mathrm{NO}_{3}{ }^{-} \mathrm{s}^{-1}$ and $-0.44 \mathrm{~mol} \mathrm{PO}_{4}{ }^{3-} \mathrm{s}^{-1}$. These high removal rates may be attributable to increased water column stability between upwelling events (Álvarez-Salgado et al., 1993). High NCP rates of $-57.2 \mathrm{mgC} \mathrm{m}^{-2} \mathrm{~h}^{-1}\left(\mathrm{NO}_{3}^{-}\right)$ and $-61.4 \mathrm{mgC} \mathrm{m}^{-2} \mathrm{~h}^{-1}\left(\mathrm{PO}_{4}{ }^{3-}\right)$ were characteristic of the dry season. These values are higher than the mean annual NCP of $-24.0\left(\mathrm{NO}_{3}{ }^{-}\right)$or $-35.8\left(\mathrm{PO}_{4}{ }^{3-}\right) \mathrm{mgC} \mathrm{m}{ }^{-2} \mathrm{~h}^{-1}$, although it must be noted that regenerated production (production from ammonium $\mathrm{NH}_{4}^{+}$) has not been considered here. The dryseason-derived NCP agrees well with the $-30 \mathrm{mgC} \mathrm{m}^{-2} \mathrm{~h}^{-1}$ $\left(-710 \mathrm{mgC} \mathrm{m}^{-2} \mathrm{~d}^{-1}\right)$ obtained from direct ${ }^{14} \mathrm{C}$ incubations in the Vigo Ria by Fraga (1976). The notable increase in productivity resulted from the wind-induced upwelling of nutrient rich ENACW (Álvarez-Salgado et al., 1996). Prego (1993a) calculated $-42 \mathrm{mgC} \mathrm{m}^{-2} \mathrm{~h}^{-1}$ for a dry season NCP in the Vigo Ria using a steady-state box model, although values up to $-117 \mathrm{mgC} \mathrm{m}^{-2} \mathrm{~h}^{-1}$ have been reported $\left(-2800 \mathrm{gC} \mathrm{m}^{-2} \mathrm{~d}^{-1}\right.$; Fraga, 1976). In the Arosa Ria, Rosón et al. (1999) derived an average dry season NCP of $-35 \mathrm{mg} \mathrm{C} \mathrm{m}{ }^{-2} \mathrm{~h}^{-1}$ (-840 mgC $\mathrm{m}^{-2} \mathrm{~d}^{-1}$ ), and proposed this result as an accurate value because it was calculated as an integration over all the contrasting hydrodynamic regimes in the ria. Our NCP for the Pontevedra Ria, therefore, agrees well with the neighbouring rias despite the differing approaches to budget modelling. Direct

\section{Resultados y discusión}

\section{Dinámica estacional de nutrientes y NCP}

\section{Estación húmeda}

Las mayores contribuciones de nutrientes por el Río Lérez tienen lugar durante la estación húmeda, con concentraciones medias de $30 \mu \mathrm{M} \mathrm{NO}_{3}{ }^{-}$y $0.12 \mu \mathrm{M} \mathrm{PO}_{4}{ }^{3-}$ en el agua fluvial. Los flujos de nutrientes difirieron de los de una mezcla conservativa y en la tabla 1 se observa como el fosfato fue retenido en la ría con una velocidad de $-0.25 \mathrm{molP} \mathrm{s}^{-1}$, mientras que para el nitrato hay una fuente de $1.74 \mathrm{molN} \mathrm{s}^{-1}$ que posiblemente proviene de una resuspensión y descomposición bacteriana aeróbica de la reserva bentónica de nutrientes. Estas observaciones para el nitrato caracterizan además el rápido reciclado del nitrógeno orgánico en relación con su consumo durante una baja actividad del fitoplancton y el dominio de los procesos físicos sobre los biogeoquímicos, como también ha sido señalado para la vecina Ría de Vigo (Prego, 1994). En base al fosfato, la NCP media de la Ría de Pontevedra desde noviembre hasta febrero fue bajo, $-20.2 \mathrm{mgC} \mathrm{m}^{-2} \mathrm{~h}^{-1}$ (tabla 1); no obstante, algunos fosfatos pueden ser retenidos por reacciones de adsorción inorgánica, ocasionando un uso aparente del mismo (Prego, 1993b). Contrariamente, el nitrato predice una remi-neralización neta en la columna de agua con una velocidad de $8.3 \mathrm{mgC} \mathrm{m}^{-2} \mathrm{~h}^{-1}$. La figura 3 muestra la evolución del $\mathrm{NO}_{3}{ }^{-}-\mathrm{NCP}$ con una tendencia hacia la heterotrofía. Ésta en el caso de la Bahía de Chesapeake, en los EUA (Smith y Kemp 1995), se atribuyó a los aportes y remineralización de materia orgánica alotóctona de origen fluvial (GPP: respiración $<1$, donde GPP es la producción primaria bruta, Gross Primary Production).

\section{Primavera}

Durante esta estación las concentraciones de nutrientes en el agua entrante a la ría desde el océano fueron inferiores a las de la época húmeda; sin embargo, tienen lugar flujos importantes cuando esporádicamente ocurren eventos de afloramiento. Esto se debe a la oxidación de materia orgánica en el agua adyacente al compartimento, esto es, sobre la plataforma continental proxima a la ría (Prego, 1994), al igual que sucede en otros sistemas de afloramiento (v.g., Friedrich y Codispoti, 1981). Los nutrientes aportados fueron asimilados por el fitoplancton que prosperó bajo un control hidrodinámico y la ría se convirtió en un sumidero de nutrientes reteniendo $-0.28 \mathrm{~mol} \mathrm{PO}_{4}{ }^{3-} \mathrm{s}^{-1} \mathrm{y}-4.58 \mathrm{~mol} \mathrm{NO}_{3}^{-} \mathrm{s}^{-1}$ (tabla 1). Los valores medios de NCP para la primavera fueron de $-21.9 \mathrm{mgC} \mathrm{m}^{-2} \mathrm{~h}^{-1}$, partiendo del nitrato, $\mathrm{y}-22.7 \mathrm{mgC} \mathrm{m}^{-2} \mathrm{~h}^{-1}$ en base al fosfato. En la Ría de Arosa se han indicado (Tenore et al., 1982) valores de $-42 \mathrm{mgC} \mathrm{m}{ }^{-2} \mathrm{~h}^{-1}$ durante la proliferación primaveral. Este sumidero de nutrientes en primavera puede considerarse como una síntesis de matería orgánica mediante nitrato costero alóctono a la ría, i.e., una producción nueva según Epply y Peterson (1979). 
measurements of GPP would be useful for drawing more direct comparisons.

\section{Conclusion}

The mean annual NCP in the Pontevedra Ria upwelling system is dependent upon the inorganic nutrient chosen for scaling to carbon units, whereby $\mathrm{NO}_{3}^{-}$predicts an NCP of $-24.0 \mathrm{mgC} \mathrm{m}{ }^{-2} \mathrm{~h}^{-1}$ and $\mathrm{PO}_{4}{ }^{3-}$ predicts $-35.8 \mathrm{mgC} \mathrm{m}^{-2} \mathrm{~h}^{-1}$. An average estuarine NCP value of $22 \mathrm{mgC} \mathrm{m}^{-2} \mathrm{~h}^{-1}\left(190 \mathrm{gC} \mathrm{m}^{-2}\right.$ $\mathrm{yr}^{-1}$ ) has been given by Boynton et al. (1982). Our results suggest an imbalance of internal fluxes and nutrient limitation; however, we have only focussed our discussion on $\mathrm{NO}_{3}{ }^{-}$and $\mathrm{PO}_{4}{ }^{3-}$, and quantification of $\mathrm{NH}_{4}^{-}$and $\mathrm{NO}_{2}^{-}$would clearly be desirable. Furthermore, $\mathrm{NO}_{3}{ }^{-}$and $\mathrm{PO}_{4}{ }^{3-} \mathrm{NCP}$ predictions are affected by denitrification and phosphorus regeneration. Shortterm upwelling enrichment events influence the trophicity of the Pontevedra Ria. The ria acts as a biogeochemical reactor, processing organic matter from inorganic starting material supported by large regular injections of inorganic nutrients to the ria during upwelling. The organic material is then exported, remineralized and re-introduced into the ria. When upwelling occurs in the wet season, large amounts of the bed nutrient stock are washed out of the system. From an inorganic nutrient standpoint, the Pontevedra Ria is net autotrophic; however, there is an alternation between heterotrophy and autotrophy in the wet season for both $\mathrm{NO}_{3}{ }^{-}$and $\mathrm{PO}_{4}{ }^{3-}$. This finding lends no support to earlier reports of a general tendency towards net heterotrophy in marine systems (Smith et al., 1991) and, therefore, the Pontevedra Ria may be considered to be naturally eutrophic.

\section{Acknowledgements}

We would like to thank Captain Jorge Alonso and the crew of the R/V Mytilus and all those who participated in the sampling campaign and nutrient analyses. The Centro Meteorológico Territorial de Galicia supplied precipitation and evaporation data and Aquagest cooperated in the Gaugin station measurements. This work was supported by CICYT under the project "Hydrodynamics and biogeochemical cycle of silicon in the Pontevedra Ria” (ref. MAR96-1782). This article is a contribution to the Spanish LOICZ programme.

\section{References}

Álvarez-Salgado, X.A., Rosón, G., Pérez, F.F. and Pazos, Y. (1993). Hydrographic variability off the Rías Baixas (NW Spain) during the upwelling season. J. Geophys. Res., 98: 14447-14455.

Álvarez-Salgado, X.A., Rosón, G., Pérez, F.F., Figueiras, F.G. and Pazos, Y. (1996). Nitrogen cycling in an estuarine upwelling system, the Ria de Arousa (NW Spain). I. Short-time-scale patterns of hydrodynamic and biogeochemical circulation. Mar. Ecol. Prog. Ser., 135: 259-273.

\section{Estación seca}

En septiembre de 1998, el caudal fluvial descendió hasta $1.4 \mathrm{~m}^{3} \mathrm{~s}^{-1}$ y sus contribuciones de nitrato y fosfato significaron menos del 3\% y 1\%, respectivamente, del total hacia la ría. Contrariamente, los aportes oceánicos desde la plataforma suministraron un $97 \%$ (nitrato) y $>99 \%$ (fosfato) de los recibidos en la ría con flujos de $15.8 \mathrm{~mol} \mathrm{NO}_{3}^{-} \mathrm{s}^{-1} \mathrm{y}$ $1.02 \mathrm{~mol} \mathrm{PO}_{4}{ }^{3-} \mathrm{s}^{-1}$. La eliminación de nutrientes aumentó de la primavera al estío hasta alcanzar tasas de $-11.98 \mathrm{~mol} \mathrm{NO}_{3}{ }^{-} \mathrm{s}^{-1}$ y $-0.76 \mathrm{~mol} \mathrm{PO}_{4}{ }^{3-} \mathrm{s}^{-1}$ (tabla 1 ), correspondiendo a la mayor parte de lo resumido anualmente dentro de la ría, que ha sido de $-5.03 \mathrm{~mol} \mathrm{NO}_{3}{ }^{-} \mathrm{s}^{-1} \mathrm{y}-0.44 \mathrm{~mol} \mathrm{PO}_{4}{ }^{3-} \mathrm{s}^{-1}$. Estas altas velocidades de eliminación pueden atribuirse a un incremento de la estabilidad en la columna de agua entre eventos de afloramiento (Álvarez-Salgado et al., 1993). En general, las altas tasas de $\mathrm{NCP}, \quad-57.2 \mathrm{mgC} \mathrm{m} \mathrm{m}^{-2} \mathrm{~h}^{-1}$ (a partir de $\mathrm{NO}_{3}^{-}$) y -61.4 mgC m ${ }^{-2} \mathrm{~h}^{-1}$ (según $\mathrm{PO}_{4}{ }^{3-}$ ) fueron características de la estación seca. Estas velocidades son mayores que las de la media anual, que tiene una NCP de $-24.0\left(\mathrm{NO}_{3}{ }^{-}\right)$ó -35.8 $\left(\mathrm{PO}_{4}{ }^{3-}\right) \mathrm{mgC} \mathrm{m}^{-2} \mathrm{~h}^{-1}$; aunque debe tenerse en consideración que la producción regenerada (esto es, a partir del amonio, $\mathrm{NH}_{4}^{+}$) no se ha tomado en cuenta. Los valores de NCP calculados durante la estación seca son concordantes con los $-30 \mathrm{mgC} \mathrm{m}^{-2}$ $\mathrm{h}^{-1}$ (-710 mgC $\left.\mathrm{m}^{-2} \mathrm{~d}^{-1}\right)$ obtenidos directamente a partir de incubaciones con ${ }^{14} \mathrm{C}$ en la Ría de Vigo por Fraga (1976). El notable incremento de la productividad es resultado del afloramiento de ENACW rico en nutrientes (ÁlvarezSalgado et al., 1996). Prego (1993 a) calculó la NCP estival en $-42 \mathrm{mgC} \mathrm{m}^{-2} \mathrm{~h}^{-1}$ para la Ría de Vigo mediante un modelo estacionario de cajas; no obstante, se han llegado a medir valores puntuales más altos, hasta $-117 \mathrm{mgC} \mathrm{m}^{-2} \mathrm{~h}^{-1}\left(-2800 \mathrm{gC} \mathrm{m}^{-2}\right.$ d ${ }^{-1}$; Fraga, 1976). En la Ría de Arosa, Rosón et al. (1999) llegaron a una NCP media para el verano de $-35 \mathrm{mgC} \mathrm{m}^{-2} \mathrm{~h}^{-1}$ (-840 $\mathrm{mgC} \mathrm{m}^{-2} \mathrm{~d}^{-1}$ ) y propusieron este resultado como un valor acertado ya que fue calculado como una integración de los diferentes regímenes hidrodinámicos en esa ría. Nuestra NCP para Ría de Pontevedra, por consiguiente, concuerda bien con los de sus rías vecinas, a pesar de las diferentes aproximaciones utilizadas para Arosa y Vigo. No obstante, sería muy útil realizar mediciones directas del GPP a fin de mejorar las referencias para los modelos de balances.

\section{Conclusión}

El promedio anual de NCP en el sistema costero de afloramiento que constituye la Ría de Pontevedra depende de los nutrientes inorgánicos de manera que, expresado en unidades de carbono, el nitrato predice una NCP de $-24.0 \mathrm{mgC} \mathrm{m}^{-2} \mathrm{~h}^{-1} \mathrm{y}$ el fosfato una de $-35.8 \mathrm{mgC} \mathrm{m}^{-2} \mathrm{~h}^{-1}$. En comparación, Boynton et al. (1982) han indicado para los estuarios una NCP media de $-22 \mathrm{mgC} \mathrm{m}^{-2} \mathrm{~h}^{-1}$ (190 $\left.\mathrm{gC} \mathrm{m}^{-2} \mathrm{a}^{-1}\right)$. Nuestros resultados sugieren un desequilibrio entre los flujos internos y la limitación de 
Boynton, W.R., Kemp, W.M. and Keefe, C.W. (1982). A comparative analysis of nutrients and other factors influencing estuarine phytoplankton production. In: V.S. Kennedy (ed.), Estuarine Comparisons. Academic Press, San Diego, pp. 69-90.

Epply, R.W. and Peterson, B.J. (1979). Particulate organic matter flux and planktonic and new production in the deep ocean. Nature, 282: 677-680.

Fiuza, A.F.G., Hamann, M., Ambar, I., Diaz del Rio, G., Gonzalez, N., and Cabanas, J.M. (1998). Water masses and their circulation off western Iberia during May 1993. Deep-Sea Res., 45: 1127-1160.

Fraga, F. (1976). Fotosíntesis en la Ría de Vigo. Invest. Pesq., 40: 151-167.

Fraga, F. (1981). Upwelling off the Galician coast, northwest Spain. In: F.A. Richards (ed.), Coastal Upwelling Series. Vol. 1. American Geophysical Union, Washington DC, pp. 176-182.

Friederich, G.E. and Codispoti, L.A. (1981). The effect of mixing and regeneration on the nutrient content of upwelling waters of Peru. In: F.A. Richards (ed.), Coastal Upwelling Series. Vol. 1. American Geophysical Union, Washington DC, pp. 221-227.

Gordon, D.C. Jr., Boudreau, P.R., Mann, K.H., Ong, J.E., Silvert, W.L., Smith, S.V., Wattayakorn, G., Wulff, F. and Yanagi, T. (1996). LOICZ (Land-Ocean Interactions in the Coastal Zone): Biogeochemical Modelling Guidelines. LOICZ Rep. Stud., 5: 1-96.

Hansen, H.P. and Grasshoff, K. (1983). Automated chemical analysis. In: K. Grasshoff, M. Ehrhardt and K. Kremling (eds.), Methods of Seawater Analysis. 2nd ed. Verlag Chemie, Weinheim, pp. 368-376.

Ibarra, E. y Prego, R. (1997). La Ría de Pontevedra: Revisión de su conocimiento. Monogr. Quím. Oceanogr., 1: 55-87.

Kemp, W.M., Smith, E.M., Marvin-DiPasquale, M. and Boynton, W.R. (1997). Organic carbon metabolism and net ecosystem metabolism in Chesapeake Bay. Mar. Ecol. Prog. Ser., 150: 229248.

McClain, C.R., Chao, S.Y., Atkinson, L.P., Blanton, J.O. and Castillejo, F. (1986). Wind-driven upwelling in the vicinity of Cape Finisterre, Spain. J. Geophys. Res., 91: 8470-8486.

Nixon, S.W., Granger, S. and Nowicki, B. (1995). An assessment of the annual mass balance of carbon, nitrogen and phosphorus in Narragansett Bay. Biogeochemistry, 31: 15-61.

Prego, R. (1993a). General aspects of carbon biogeochemistry in the ria of Vigo, northwestern Spain. Geochim. Cosmochim. Acta, 57: 2041-2052.

Prego, R. (1993b). Biogeochemical pathways of phosphate in a Galician Ria (North-western Iberian Peninsula). Estuar. Coast. Shelf Sci., 37: 437-451.

Prego, R. (1994). Nitrogen interchanges generated by biogeochemical processes in a Galician ria. Mar. Chem., 45: 167-176.

Prego, R., Dale, A.W. deCastro, M., Gómez-Gesteira, M., Taboada, J.J., Montero, P., Villareal, M.R. and Pérez-Villar, V. (2001). Hydrography of the Pontevedra Ria: Intra-annual spatial and temporal variability in a Galician coastal upwelling system (NW Spain). J. Geophys. Res., 106: 19845-19858.

Ríos, A.F. y Fraga, F. (1987). Composición química elemental del plancton marino. Invest. Pesq., 51: 619-632.

Rosón, G., Álvarez-Salgado, X.A. and Pérez, F.F. (1999). Carbon cycling in a large coastal embayment affected by wind-driven upwelling: Short-time-scale variability and spatial differences. Mar. Ecol. Prog. Ser., 176: 215-230.

Smith, E.M. and Kemp, W.M. (1995). Seasonal and regional variations in plankton community production and respiration for Chesapeake Bay. Mar. Ecol. Prog. Ser., 116: 217-231. nutrientes; no obstante, la discusión se ha centrado en balances de $\mathrm{NO}_{3}{ }^{-}$y $\mathrm{PO}_{4}{ }^{3-}$ y sería conveniente cuantificar también los de $\mathrm{NH}_{4}{ }^{-}$y $\mathrm{NO}_{2}{ }^{-}$a parte de que las predicciones basadas en nitrato y fosfato se pueden encontrar afectadas por la desnitrificación o por la regeneración de fósforo.

Los eventos de enriquecimiento a corta escala por el afloramiento afectan la eutrofía de la Ría de Pontevedra. La ria actúa como un reactor biogeoquímico elaborando materia orgánica a partir de las sustancias inorgánicas aportadas por las contínuas e importantes llegadas de sales nutrientes a la ría durante los eventos de afloramiento. La materia orgánica sintetizada es entonces exportada, remineralizada y reintroducida en la ría. Cuando un afloramiento sucede en la estación húmeda grandes cantidades de las reservas de nutrientes contenidas en su lecho son transportadas fuera de la ría.

Desde el punto de vista de las sales nutrientes y su balance, la Ría de Pontevedra es autotrófa; sin embargo, de acuerdo con los flujos de nitrato y fosfato, existe una alternancia entre su autotrofía y heterotrofía durante la estación húmeda y, por lo tanto, la Ría de Pontevedra puede ser considerada como naturalmente eutrófica. Este hallazgo no apoya la clásica idea de que hay una tendencia general de los sistemas marinos hacia la heterotrofía (Smith et al., 1991).

\section{Agradecimientos}

Deseamos dar las gracias al Capitán Jorge Alonso y a la tripulación del B/I Mytilus, al igual que a todas las demás personas que participaron en las campañas de muestreo o colaboraron en los análisis de nutrientes; también al Centro Meteorológico Territorial de Galicia por los datos de lluvia y evaporación y a Aquagest por su colaboración en el aforo del Río Lérez. Este trabajo fue financiado a través del proyecto CICYT (ref. MAR96-1782) "La hidrodinámica y el ciclo biogeoquímico del silicio en la Ría de Pontevedra” y es una contribución al programa español de LOICZ.

Traducido al español por los autores.

Smith, S.V. and Hollibaugh, J.T. (1997). Annual cycle and intertidal variability of ecosystem metabolism in a temperate climate environment. Ecol. Monogr., 67: 509-533.

Smith, S.V., Hollibaugh, J.T., Dollar, S.J. and Vink, S. (1991). Tomales Bay metabolism: C-N-P stoichiometry and ecosystem heterotrophy at the land-sea interface. Estuar. Coast. Shelf Sci., 33: 223-257.

Tenore, K.L., Boyer, L.F., Cal, R.M., Corral, J., García-Fernández, C., González, N., González-Gurriaran, E., Hanson, R.B., Iglesias, J., Krom, M., López-Jamar, E., McLain, J., Pamatmat, M.M., Pérez, A., Rhoads, D.C., de Santiago, G., Tietjen, J., Westrich, J. and Windom, H.L. (1982). Coastal upwelling in the Rias Bajas, NW Spain: Contrasting the benthic regimes of the rias de Arosa and Muros. J. Mar. Res., 40: 701-772.

Wooster, W.S., Bakun, A. and McClain, D.R. (1976). The seasonal upwelling cycle along the eastern boundary of the North Atlantic. J. Mar. Res., 34: 131-141. 